$\mathrm{K}$

STUDIA Z PRAWA WYZNANIOWEGO

Tom $23-2020$

DOI: https://doi.org/10.31743/spw.9696

\author{
BALÁZS SCHANDA*
}

\title{
HUNGARY'S CHRISTIAN CULTURE AS SUBJECT OF CONSTITUTIONAL PROTECTION
}

\section{Abstract}

Since 2018 the Fundamental Law of Hungary (the Constitution) has provided for the protection of the Christian culture of Hungary as an obligation of all organs of the State. The Fundamental Law does not commit the Hungarian State to Christian religion or to Christian culture in general, but specifically to the cultural tradition of the country. Despite the recognition of the cultural role of Christianity, the Constitution remains neutral with regard to religion and the freedom of religion is recognised. The constitutional provision discussed in this study, i.e. Article R) para. 4, expressly identifies the culture of Hungary as a culture shaped by Christianity. Culture was born from faith, but faith cannot be born from a historic legacy and even less from a constitutional provision. Thus, the aim of the constitutional legislator was undoubtedly to place a stronger emphasis on the identity of the nation.

Key words: constitutional identity; Christianity; culture; Hungary

$* * * * *$

* Judge at the Constitutional Court of Hungary, Professor at Pázmány Péter Catholic University, Faculty of Law and Political Sciences, Department of Constitutional Law; 1088 Budapest, Szentkirályi u. 28, Hungary; e-mail: schanda.balazs@jak.ppke.hu, https:// jak.ppke.hu/en/teaching/faculty-members-and-researchers/schanda-balazs-b071a. 


\section{INTRODUCTION}

According to Article R) para. 4 of the Fundamental Law of Hungary ${ }^{1}-$ the paragraph was introduced by the seventh amendment to the Fundamental Law in 2018 - ' $[\mathrm{t}]$ he protection of the constitutional identity and Christian culture of Hungary shall be an obligation of every organ of the State'. ${ }^{2}$ The Fundamental Law does not commit the Hungarian State to Christian religion or even to Christian culture in general, this way it is neutral with regard to religion. But it expressly orders it to protect the culture of Hungary as a Christian culture. The aim of the constitutional legislator was undoubtedly to afford the identity of the nation with a stronger emphasis and protection; formerly, that is before the seventh amendment, national identity was only protected by a reference contained in the Fundamental Law's preamble - the so called 'National Avowal' - where the 'Christian heritage' is mentioned. ${ }^{3}$ The new wording of the constitutional provision raises the question if Christianity can be protected by a constitution? Can the state uphold a culture rooted in Christianity? If culture can be seen as the fruits of religion, what happens if wide parts of society lose their faith? Can fruits be protected without living roots? This article is an attempt to answer these questions.

\section{CHRISTIAN HERITAGE IN THE NATIONAL AVOWAL}

According to the accurate definition put forward by Antal Szerb in 1934, 'Hungarian intellectual life was born on the day the nation became Christian. Hungarian culture is fundamentally a Christian culture, similarly to the Church's oldest daughter, French culture, and is not a 'con-

1 Fundamental Law of Hungary, adopted on 18 April 2011, in force since 1 January 2012, last amended on 28 June 2018 ('seventh amendment'). For a general overview of the Constitution see Varga, Patyi and Schanda (eds.) 2015.

2 https://njt.hu/translated/doc/TheFundamentalLawofHungary_20190101_FIN.pdf

3 The first sentence of the National Avowal reads as follows: 'We are proud that our king Saint Stephen built the Hungarian State on solid ground and made our country part of Christian Europe a thousand years ago'. A later section proclaims: 'We recognize the role of Christianity in preserving the nation. We honour the various religious traditions of our country'. 
verted' culture like that of the Germanic peoples'. ${ }^{4}$ This message remains valid today: 'That is why all attempts to use the German example to search for the fulfilment of Hungarian culture in invisible, pre-Christian paths is both perverse and comical'. ${ }^{5}$ Although we do not necessarily have to choose between the Christian and the pre-Christian legacy of the nation for example between the State founder King Saint Stephen (977-1038) on the one hand and Árpád (845-907; the ruler during the conquest of the Carpathian basin from 895 to 907$)^{6}$ on the other hand - doing so is sometimes inevitable: by choosing Christianity, Hungary opted to follow the heritage of Saint Gerard of Venice (980-1046), bishop and martyr, instead of that of his pagan Hungarian murderers.

The preamble of the Fundamental Law (the National Avowal) is centred on the invocation of Saint Stephen and Christian Europe ${ }^{7}$ and makes no reference to the period preceding Statehood, that is, the Fundamental Law considers the founding of the State and not the Hungarian conquest of the Carpathian Basin its historical point of origin. Accordingly, the last sentence of the first paragraph in the preamble expressly acknowledges the role of Christianity in preserving the nation's identity. This recognition relates neither to the role of Christianity as a religion nor to the role that the Christian faith currently plays in Hungarian society but rather pertains to the determining role played by Christianity in the nation's history. There is no question that Christianity not only plays a role in preserving nationhood and that it is more than just a tradition. The tradition goes beyond the role of Christianity and Christianity is present today as well. It is important to realize that the National Avowal stops at the instrumental invocation of the Christian tradition. The National Avowal is a descriptive finding of a historical fact and does not lay down an obligation to resurrect that history. The constitutional legislator is merely recognising

4 Szerb 1992, 29. Szerb has authored a determining monograph on the history of Hungarian literature. He was murdered in January 1945 in forced labour that he served because of his Jewish descent.

5 Szerb 1992, 29.

61,069 streets or squares commemorate Árpád who headed the pagan Hungarian tribes arriving on the Carpathian basin in 895. Saint Stephen is commemorated by 379 streets or squares. See Csik-Kovác and Papp 2011, 166.

7 Chronowski 2011, 68, 75; Tóth 2013. 
a historical fact, and does so from the viewpoint of the nation as the legislating community, besides recognizing various other religious traditions of the country as well. While the importance of Christianity in history is indisputable, it cannot be stated that Christianity plays an exclusive role in today's world - which the preamble does not state either. The National Avowal pays tribute to religious traditions; however, the recognition of non-religious traditions is missing ${ }^{8}$ just as any mentioning of the role that religion plays in the world or even in Hungary nowadays.

Although a third of the new Fundamental Law of 2011 is verbatim identical to the previous Constitution ${ }^{9}$ - and the content of another third is identical too, the overall picture the new Fundamental Law presents is indeed a fundamentally new one. ${ }^{10}$ The novelty is mainly due to the fact that the Fundamental Law now shows a stronger commitment than its predecessor had done to both the cultural identity of the political community (the nation) and the values that drive that community. The framework of the constitutional law now builds upon the values that precede the law and that ensure the cohesion of the national community - as we are well aware that the State itself cannot create or maintain these values. ${ }^{11}$ Our relationship with these values - with the traditions and with the anthropological issues behind the legislative system - is of paramount importance. Although specific constitutional norms (and thus fundamental rights) had an intrinsic value before 2011 as well, the Constitution had not explicitly referred to the values it was based upon. The Constitutional Court of Hungary also avoided referring to the system of the Constitution's values while consciously striving to expand the scope of the Constitution's values and urging society to be permeated by them. ${ }^{12}$ The Fundamental Law has created something new with the pronounced commitment to values. Whether the conveyed values and traditions divide or unify society is not just a question of chance but may be a result of

8 Jakab 2011, 181.

9 Constitution of Hungary adopted on 20 August 1949 - gradually amended in 1989/90: this former Constitution lost its force by virtue of the new Fundamental Law in 2011 .

10 Csink and Fröhlich 2012, 108.

11 This reminds of the Böckenförde-Diktum: 'Der freiheitliche, säkularisierte Staat lebt von Voraussetzungen, die er selbst nicht garantieren kann’. Böckenförde 1976, 60.

12 Sólyom 2001, 140, 144. 
a conscious effort. This work depends partly on politics promoting unity as well as the proper functioning of the State, but the values behind the Fundamental Law must be recreated generation after generation by society itself and not by the State.

The Fundamental Law's commitment to religion and the current role of religious communities cannot be inferred from the text of the National Avowal; it does not mention communities other than the family or the nation. It specifically does not mention churches and religious communities, although they make up the fabric of our society: the fabric without which a democratic State cannot exist but which the State cannot recreate or maintain itself - as it flows from the 'Böckenförde Dilemma'. ${ }^{13}$ It cannot be claimed that, in general, the Fundamental Law fully adopts the Christian tradition or that it institutionalises it; any such commitment may be found only in respect to certain legal institutions, e.g., the institution of marriage, which is defined in the Fundamental Law. ${ }^{14}$ Instead of providing for an institutionalised state religion, the Fundamental Law rather promotes the commitment to values while maintaining the State's neutrality as regards religion and morals. ${ }^{15}$ With a peculiar, inclusive interpretation, Christian morals can be applied to the pre-communist historical constitution's achievements, as the interpretative background of the Fundamental Law. ${ }^{16}$ Although Ádám Rixer links natural law to Christianity and refers to the historical Constitution's medieval roots, he also states that the historical Constitution is connected to the system of Christian values. ${ }^{17}$

The first line of the National Anthem ('God bless the Hungarians'), as a motto of the Fundamental Law, is not an invocatio Dei in its traditional sense: the Fundamental Law is not created in the name of God (as is

13 See fn. 10.

14 Article L (1): 'Hungary shall protect the institution of marriage as the union of a man and a woman established by voluntary decision, and the institution of family as the foundation of the substance of the nation. Family ties shall be based on marriage or the relationship between parents and children'.

15 Concurring opinion: Tóth 2012, 67, 74; Pap 2014, 686.

16 Rixer 2018, 93. The term 'historical Constitution' refers to the pre-communist Constitution of Hungary that has never been codified into a single document but consisted of the historically developed set of statues as well as the general consensus on certain principles.

17 Rixer 2011. 
the case with the Swiss Constitution or the Irish Constitution, for example). Something that requires an explanation for foreigners is quite clear to Hungarians even without the use of quotation marks: the purpose of the reference preceding the normative text of the Fundamental Law is to link all of the nation's members (originally the National Anthem was written in 1823 and it became the official anthem by customary law in the late 1800s). Assuming healthy relations, although that the National Anthem contains an additional meaning for religious citizens, it does not mean that it excludes those who oppose this additional meaning or who are indifferent to this added content. János Zlinszky's notion that 'the addressee of the order cannot be instructed to act on the basis of the legal text ${ }^{\prime}{ }^{18}$ is more ironic than anything else - and it also illustrates the limits of the National Anthem's normative nature. The first sentence of the Fundamental Law has a very important symbolic significance, its legal significance is not as pronounced. ${ }^{19}$ Although it is impossible to interpret the quoted line without knowing the context, a reference to God cannot be a goal unto itself: it is a recognition of the finite nature of power - in this case, the finite nature of constitutional power - which protects the people and not God (who hardly requires such protection). This is made especially clear in the text of the postamble (which is reminiscent of the Bonn Basic Law): the expression ' (...) being aware of our responsibility before God and man (...)' does not mean that the State desires sacral legitimacy, but rather that it acknowledges its own limited nature and moral responsibility.

The aspect which the seventh amendment of the Fundamental Law changes therefore is the following: the seventh amendment declares that Hungary's Christian culture has to be protected (and not the Christian faith or religion).

\section{THE PRESCRIPTIVE ORDER TO PROTECT CHRISTIAN CULTURE}

By decreeing the protection of Hungary's Christian culture, the legislator intends to ensure that Christianity - or, more precisely, Hungary's

18 Zlinszky 2011, 26, 27.

19 Horkay Hörcher 2012, 25. 
Christian-based culture - is present not only as a respected element of the past but also as a present value that is to be protected. Stemming from its nature, Christianity is a universal religion that has strived for inculturation ever since the outset (with varying degrees of success). The Fundamental Law requires the protection not of Christianity (or its applicable inculturated version), but of a cultural reality. We know a number of examples from history where faith, in its transformation of individuals and its yeast-like permeation of society, creates culture. However, constitutional protection is provided not to the Christian faith, but to the culture that it has created, including the freedom to oppose that culture. It is impossible to afford constitutional protection to the Christian faith itself (and law does not protect against temptations); the most that law can do is to remind the holders of public power of their special responsibility for the common good, just as the above quoted closing sentence of the Fundamental Law does: responsibility cannot be limited to a single election, no matter how important it may be, but it encompasses all of life.

By definition, protection assumes a threat. As claimed by the supporters of the changes to the Constitution discussed above, the amendment was necessary due to processes (that remained unspecified and unnamed) taking place in Europe and its goal was to uphold the cultural image of Europe and Hungary. ${ }^{20}$ Neither this new addition to Article R) of the Fundamental Law nor the justification specify whether the change in the continent's cultural image is due to the altered composition of the population which in turn is due to migration processes, secularisation, social apostasy, or any other factor that has to be combatted according to the vision of the amendment; rather, Article R) of the Fundamental Law leaves wide room for interpretation. Whether these processes can be influenced by means that constitutional law has at its disposal is another question: if societies characterised by long-standing, strong commitments (think of Belgium, Ireland, and Spain) turn against not only Christian traditions but even natural law in the area of legislation, ${ }^{21}$ is that attributable to secularisation, the weakness of the Church, or the negligence of the legis-

20 Motion of the Parliamentary Commission on Legislation, 14 June 2018, seehttp:// www.parlament.hu/irom41/00332/00332-0011.pdf [access: 27.3.2020].

21 Frivaldszky 2016, 74. 
lator? These examples show that the will of the people may shift from behind constitutional rules, and that constitutional and legislative provisions may be altered to reflect the changed will of the popular majority in a time span of no more than one generation. We cannot forego the fact that in Western Europe, the rift regarding the protection of life, the definition of marriage, or even the use of crucifixes in public buildings is not between Muslims and Christians but rather between those who adhere to religious traditions and those who adhere to secular forces.

Culture primarily means the totality of the material and intellectual values created by humanity, the manifestation of the learning of a community or people. From an anthropological perspective, culture is the way of life of a community. ${ }^{22}$ Threats to our culture may come from various directions - as the wording of the Fundamental Law is quite general, it conveys a message of support for those striving to protect cultural heritage, be it the protection of a cityscape, the maintenance of cultural traditions, or the emphasising of the importance of teaching the Latin language. However, a general reference is also made to the whole of the Central European way of life, which includes everything from music education through dance schools to the evaluation and protection of partnerships, forms of behaviour, and virtues. It would be impossible to define the entire scope of the content of our culture the State is to protect. Whether this culture can indeed be deemed Christian or whether it would be more appropriate to talk of a Christian-rooted culture still needs clarification.

While the National Avowal acknowledges the Christian heritage, the newly added para. 4 of Article R) of the Fundamental Law provides for the protection of Christian culture, noting that accepting a certain heritage not only includes the positive aspects, as it can also contain negative elements: assets and debts are inherited together. The new prescription is not about the recognition or the protection of the Christian faith or Christian religion, but about protecting the culture rooted in the faith and religion. This may seem to be a contradiction: in general, Christian culture cannot be interpreted without the Christian faith, as culture is a product of the faith. The works of Dante and Bach resonate from centuries of traditions and a deep individual conviction, and they elevate the Di-

22 Pusztai (ed.) 2003, 774. 
vine Comedy and the Passion of Saint Matthew to the level of theological works; ripping them from their roots means they can be understood only in part, not disputing the fact that performers who do not share the faith of the artists can interpret the works of Bach, Händel, and Zoltán Kodály. Such a reflection cannot be created by legislative means. Although the definition of Christian culture is much broader than the artistic expression of culture, the fate of artistic expression and works of art is a good example of our relationship with our roots: that is how it can be that a painting of Saint Elizabeth by the cubist-expressionist painter Sándor A. Tóth from 1937 is auctioned off with the title 'Art deco woman with flowers' ${ }^{23}$ On the one hand, it is clear that the recognition of artistic value is in itself a value even if the original intent is not recognised: the painting appeals not only to religious viewers. However, it feels as if something has been lost...

The social practice that is irreconcilable with the Christian faith enjoys exactly the very freedom that stems from Christianity. A significant part of Hungarian society, including those who consider themselves Christian, do not follow numerous moral commandments and traditions stemming from Christianity: Christian culture protects this freedom to depart from traditions as well. Contrary to religion-based legal systems (like those of countries adhering to Islamic law), religious truth does not in itself provide a basis for differentiating between lawful and illegal conduct: only those norms can become legal norms that are rational and socially acceptable. While providing law with a secular foundation might seem absurd in traditional, religion-based legal systems, legislators in a secular state cannot base the criminalisation of murder or the regulation of economic crimes solely on the Ten Commandments.

In connection with the National Avowal, András Jakab refers to the saying previously attributed to former Prime Minister József Antall, according to which even atheists are Christians in Europe. ${ }^{24}$ This can be said to be true from a cultural perspective: regardless of denominations, name days are celebrated all over Hungary, a tradition which has been adopted by non-Christians as well - or differently: a tradition that has been upheld

23 http://www.kieselbach.hu/alkotas/art-deco-no-viragokkal_-1937_17740 [access: 27.03.2020].

24 Jakab 2011, 180. 
even by those who have parted with religion and now hold secular views. Many official forms ask for a person's 'Christian name' instead of using the neutral term 'forename'. The question arises whether these traditions, if they no longer convey their original meaning, are worrying specifically to devout believers; at the same time, we would not consider it fair if Saint Nicholas were to give presents only to Catholic children (ultimately, the right approach to the tradition is not from the viewpoint of Saint Nicholas, but that of the children and their interest in having equal, or rather general access to chocolate).

While the decision as to what is reconcilable with the Christian faith is a question to be decided by ecclesiastical communities and their ministers, and it is also a question of conscience, it remains up to the Constitutional Court to interpret the Fundamental Law. How can the commitment to Christian culture be interpreted?

\subsection{THE PURPOSE OF THE STATE - 'SOLLEN'?}

The protection of Christian culture may mean banning miniskirts, but it may also mean the freedom to wear them. Which interpretation is correct?

Can constitutional provisions be understood as goals of the State, i.e. does the State consider it to be its obligation to direct society's decisions so as to realize the values of the Christian faith? Stronger protection for human life beginning at conception; the protection of the sacred bond of marriage; the restriction of working on Sundays, of pornography, of the feeling of nostalgia for esoterica and ancient pagan Hungarian history, and of the use of non-Christian first names; doing away with blasphemous expressions in the common terminology of the armed forces; the fight against tattoos, drug use, and gambling; strong solidarity with the most vulnerable members of society; the validation of subsidiary in the organisation of society and the economy, etc.? In a number of issues there is a deep gap between the Christian faith and a general social attitude. In a number of cases there is a division between the current social practices (undertaken, in all certainty, by the majority of voters) and the Christian approach (even if subconscious). The endeavours of Christian voters and politicians to have their faith manifested in the legal system and the politics of the State is legitimate; however, the reasons for validating their viewpoint 
have to be approachable for everyone and cannot be purely theological; Christian voters and politicians must gain majority support for their arguments by way of a democratic decision-making process.

If we consider the protection of Christian culture to be, indeed, the State's goal, we could expect the State to display active conduct to ensure that society's selection of values is in line with Christian traditions, i.e. to promote the birth and maintenance of Christian culture. Thus, in addition to the aspects of legality and expediency, all State bodies would have to weigh how a given decision can be evaluated from the aspect of Christian culture.

\subsection{PROTECTION OF THE EXISTING SYSTEM OF VALUES - 'SEIN'?}

The wording of the Fundamental Law, however, shows that the legislator targets the protection of present social practices and not the re-creation of a pure Christian culture, even in cases where there is a gaping abyss between Christian ideals and social practices. This is also indicated by the fact that the Fundamental Law demands the protection of a specific culture (in this case: Hungary's Christian culture) and not the protection of Christian culture in general; only the latter could include turning Hungary's actual culture into a fully Christian culture. To return to the above-mentioned example, it seems that the legislator was led not by the desire to ban miniskirts (or indecent clothing in general), but to protect the right to wear them. If the culture of Europe - and thus of Hungary - is Christian, ${ }^{25}$ the protection of cultural self-identity can only mean the protection of a Christian culture.

\subsection{THE RELATIONSHIP BETWEEN CHRISTIAN CULTURE AND CHRISTIAN FAITH}

That faith may create culture is an experience derived from history. ${ }^{26}$ The culture that grew from Christianity can be protected organically only together with Christianity. With its order to protect culture, the Fundamen-

25 The identity of Europe is defined by its Christian heritage. See Weiler 2004; Király 2006, 67-72; Pünkösty 2014.

26 Török 2016, 16. 
tal Law and the State are only able to protect the resulting consequences. Without people actually living the faith, the fruits of that faith - the fruits of the faith of our predecessors - will be preserved for just a short while, maybe a generation or two. With its order to protect culture, the Fundamental Law protects not the tree (the Christian faith) - the protection of which could not be undertaken by the Fundamental Law - but only the fruits of that tree. The legislator has no influence over whether the tree is alive or if it is merely the skin, the visible shell of the fruit that we are protecting, ripped from the tree.

A peculiar question is whether the State can take action against those who actually voice Christian viewpoints based on theological principles or a moral basis in the interest of protecting the given culture of today. If we identify 'Christian culture' with today's predominant forms of behaviour and actual practices, 'Christian culture' (perhaps Christian in its roots but not in its content) may actually directly oppose the authentic Christian position. ${ }^{27}$ The Christian faith can easily lead to criticism of existing Christian (-based) culture. The protected sphere of the freedom of religion includes the freedom of individuals, religious communities, and leaders to formulate positions on religious or moral issues, which rightfully pose a challenge to the existing cultural milieu. Outsiders may not question the credibility of their positions, religious principles, and moral views. However, the question of whether the criticism is aimed at the renewal or destruction of the (fundamentally) Christian culture is quite important. In both cases, the freedom of criticism is protected by the right of free speech and thus by Christian culture.

With the loss of faith culture loses ground. Taking the secularization of Europe into account (including the self-secularization of churches $^{28}$ ), we observe a new generation growing up for whom the Christian termi-

27 An example of a sharp critique of the government proud of its pro-Christian politics could be the homily given by the President of the Hungarian Bishops' Conference András Veres condemning the expansion of the in-vitro fertilisation programs at Saint Stephen's day on August 20, 2017; https://www.magyarkurir.hu/hirek/megteresre-es-megujulasra-hivott-veres-andras-budapesten-allamalapito-szent-kiralyunk-unnepen [access: 27.03.2020].

28 The term used by Pope Benedict XVI: Address of His Holiness Benedict XVI to Bishops of the Episcopal Conference of Brazil; http://w2.vatican.va/content/benedict-xvi/ 
nology has no meaning at all. Christmas remains to be a holiday for all but a Christmas tree does not have a stronger link to Christ than our Latin heritage has to the Romans. Preserving the Latin names for months does not remind us of the Roman Emperors over the summer. The heritage is still there but it is not a vivid one any more. Christianity was born outside of Europe but it has gained its most effective cultural and intellectual form here. ${ }^{29}$ As Pope Benedict XVI put it: The present culture determining Europe was also born here but this is more a culture of scientific rationalism excluding God from the common space. We do not live in Christian culture any more but in a positivist and agnostic one that has become intolerant to Christianity. ${ }^{30}$

\section{THE ISSUE OF NEUTRALITY}

The Fundamental Law does not mention the principle of State neutrality in religious or moral matters, just as it was not mentioned by the previous Constitution, either. However, the text of the Fundamental Law does not list any commitment that would exclude neutrality, and there have been no essential changes to the wording of fundamental rights from which the principle of neutrality stems (freedom of conscience and religion, the prohibition of negative discrimination). Based on the above, it cannot be argued that the Fundamental Law's stronger commitment to values would move it away from the principle of moral neutrality. Accordingly, the findings on the State's neutrality in matters of religion and morals as originally worded by the Constitutional Court of Hungary ${ }^{31}$ continue to apply and form part of Hungary's constitutional law. The State's religious and moral neutrality was confirmed by new Acts that entered into force simultaneously to the new Fundamental Law, thus, for example, in the preamble to the Act on

en/speeches/2009/september/documents/hf_ben-xvi_spe_20090907_ad-limina-brasile.html [access: 27.03.2020].

29 Ratzinger 2005, 32.

30 See Benedict XVI 2016.

31 Constitutional Court, decision no. 4/1993, 12 February 1993. 
the Right to Freedom of Conscience and Religion ${ }^{32}$ and the Act on the System of the National Public Education, ${ }^{33}$ which guarantees the right to an education which is neutral on matters of religion and morality. In these Acts, the legislator clearly differentiates between religious and moral neutrality and the neutrality of culture and values: the Fundamental Law stands firmly on the ground of religious neutrality while rejecting the neutrality of culture and values. The new addition to Article R) of the Fundamental Law does not change this stance.

Neutrality does not mean indifference: a neutral state is not a state devoid of values and does not live in a 'vacuum'. A significant part of the values and the culture that provide the foundation of any statehood are determined by history and society. As a certain form of a certain community's organisation in a specific historical environment, the State cannot forego and cannot avoid the existing values that surround and carry it. While refraining from taking on their identity, the State does not have to worry about granting recognition and support to the communities and institutions that promote values. Besides its neutrality, the State that is neutral in moral issues would not take heed of the religious aspects and needs of its citizens. This would unavoidably give preference over those who have no such needs. However, within the meaning of neutrality under Hungarian constitutional law, both positive and negative aspects of religious freedom are of equal value, i.e. neither can be considered the general rule to which the other merely forms an exception.

Neutrality is in no way an ideology: the State does not represent neutral morals, as, even if there were such a thing as neutral morals, the State would have to be neutral in respect of such morals, as well. The issue is much more that of organising the coexistence of people with different faiths and morals, while aiming to minimise the burdens borne by individuals and communities stemming from these differences: nobody may end up in a position where they feel like 'second-class' citizens due to their identity. Certainly, neutrality is binding upon the bodies of the State and not on its citizens.

32 Act CCVI/2011 on the Right to Freedom of Conscience and Religion and the Legal Status of Churches, Denominations and Religious Communities.

$33 \S 74$ (3), Act CXC/2011 on the System of National Public Education. 
According to further assumptions regarding the neutrality of the State on matters of morals, the State has to avoid taking a position on all issues in which there is no social consensus in order not to influence society on a given issue. However, in Hungarian constitutional law neutrality can only exist in specific cases. ${ }^{34}$ Moreover, the principle of neutrality in constitutional law originates not from American sociological and philosophical thought but rather from German legal doctrine. Similarly to Hungary, the term was introduced to Germany by the German Constitutional Court, which stated that the State, as 'a home for all citizens', must be neutral. ${ }^{35}$ However, this neutrality in no way excludes the State resolutely siding with certain values in the areas of public ecclesiastical law, family law or tax policy.

The State's role in protecting the Christian heritage does not raise any concerns precisely at the point where heritage has become culture. The approach to tradition is hardly uniform, just as the cultural identity of the political community is not homogeneous. There is a myriad of examples to illustrate this fact, from the symbols used on the coins and bills minted by the central bank through the heraldry of municipalities to the practice of naming public areas and institutions. Even expressly religious motifs can be considered cultural traditions instead of manifestations of faith, for example when we think of the fact that in 2007 the liberal leadership of the city of Budapest invited a priest to bless the drill used for metro line 4. This is more than just reviving the lost traditions (such as reinstating the word 'saint' in the names of Budapest's hospitals), as new institutions also received similar names in a number of cases (for example, the hospital in Dunaújváros was named after Saint Pantaleon in 1991 - that is the patron Saint of the village close to the industrial city constructed in the early years of the communist regime). The decision regarding the amount and type of content that the public can accept without tension as regards the names of public areas or community institutions (including public education institutions and public service mass communication media) requires sensitivity on behalf of decision makers rather than abstract regulation. The lantern festival on Saint Martin's Day and the Nativity plays put on in municipal kindergartens seem like quaint traditions rather than the forceful

34 Paczolay 1993, 129-135.

35 Federal Constitutional Court (Germany), BVerfGE 12, 1, 5. 
spreading of religion. However, kindergarten teachers have to pay attention to whether the celebrations are uncomfortable to some parents due to their beliefs: children must not feel discriminated against, but a situation must not arise where we expect only the members of the majority to adapt, as this leads to emptiness and not neutrality.

\section{CONCLUSION}

Just as the constitutional recognition of the historical role of Christianity is not irreconcilable with the principle of State neutrality on matters of religion, neither is the recognition of the cultural role of Christianity and the protection of culture based on Christian traditions. The protection of Hungary's Christian culture is not the same as ordering that a Christian culture be created - or re-created - but it is rather a commitment to protect a specific culture existing in Hungary nowadays. The protection of culture is a legitimate task of the State, though the State is not capable of developing and maintaining the basis of that culture: the development and safekeeping of Christian culture remains the responsibility of Christians (both individuals and communities) and not that of the State. From the other perspective: those understanding the foundations of the culture of a nation bear a special responsibility for preserving it.

\section{REFERENCES}

Address of His Holiness Benedict XVI to Bishops of the Episcopal Conference of Brazil; http://w2.vatican.va/content/benedict-xvi/en/speeches/2009/september/documents/hf_ben-xvi_spe_20090907_ad-limina-brasile.html

Benedict XVI. 2016. Last testament in his own words. London: Bloomsbury. Böckenförde, Ernst-Wolfgang. 1976. Staat, Gesellschaft, Freiheit: Studien zur Staatstheorie und zum Verfassungsrecht. Frankfurt am Main: Suhrkamp. Chronowski, Nóra. 2011. "Az Alaptörvény európai mérlegen”. Fundamentum 2: 68-80.

Csink, Lóránt and Johanna Fröhlich. 2012. Egy alkotmány margójára. Alkotmányelméleti és értelmezési kérdések az Alaptörvényröl. Budapest: Gondolat. 
Csik-Kovác, Zoltán and Gábor Papp. 2011. “Kossuth vs. Petőf”. In: Magyarország szubjektív atlasza, ed. by Annelys de Vet, Attila Bujdosó, 166, Budapest: Kitchen Budapest - HVG Könyvek.

Frivaldszky, János. 2016. Jó kormányzás és a közjó. Politikai és jogfilozófiai szemszögbőll. Budapest: Pázmány Press.

Horkay Hörcher, Ferenc. 2012. "The National Avowal”. In: The Basic Law of Hungary: A First Commentary, ed. by Balázs Schanda, Lóránt Csink and András Zs. Varga, 25-46. Dublin: Clarus Press.

Jakab, András. 2011. Az új Alaptörvény keletkezése és gyakorlati következményei. Budapest: HVG-Orac.

Király, Miklós. 2006. "Európa keresztény gyökerei és az alkotmányos szerződés". Iustum Aequum Salutare II/3-4: 67-72.

Paczolay, Péter. 1993. “Az állam semlegességének mítosza?” Politikatudományi Szemle II/3: 129-135.

Pap, András László. 2014. “Az Alaptörvény preferenciáiról”. Magyar Jog 61/12: 686-698.

Pünkösty, András. 2014. Az európai uniós jog etikai vonatkozásai. Kritikai elemzés, különös tekintettel az Egyház társadalmi tanitására. Budapest: Pázmány Péter Katolikus Egyetem ( $\mathrm{PhD}$ thesis).

Pusztai, Ferenc. 2003. Magyar értelmezö kéziszótár. Budapest: Akadémiai.

Ratzinger, Joseph. 2005. Benedek Európája a kultúrák válságában. Budapest: Szent István Társulat.

Rixer, Ádám. 2011. “A történeti alkotmány lehetséges jelentéstartalmai”. Jogelméleti Szemle 3 (http://jesz.ajk.elte.hu/rixer47.html).

Rixer, Ádám. 2018. A vívmány-teszt. Budapest: Dialóg Campus.

Sólyom, László. 2001. Az alkotmánybiráskodás kezdetei Magyarországon. Budapest: Osiris.

Szerb, Antal. 1992. Magyar irodalomtörténet. Budapest: Magvető Könyvkiadó.

Tóth, Gábor Attila. 2012. “«Az Alaptörvény fő problémái nem oldhatók meg jogértelmezéssel». Tóth Gábor Attila alkotmányjogásszal Sólyom Péter beszélget". Fundamentum 4: 67-75.

Tóth, Zoltán J. 2013. "Az Alaptörvény szellemisége: a Nemzeti hitvallás értékei, a jogfolytonosság és az Alapvetés”. Polgári Szemle 9/3-6: 275-293.

Török, Csaba. 2016. A kultúrák Lelke. Budapest: Új Ember.

Varga, András Zs., András Patyi and Balázs Schanda, Patyi (eds.). 2015. The Basic (Fundamental) Law of Hungary. A Commentary of the New Hungarian Constitution. Dublin: Clarus Press.

Weiler, Joseph H. H. 2004. Ein christliches Europa: Erkundungsgänge. Salzburg München: Anton Pustet Verlag. 
Zlinszky, János. 2011. "Észrevételek az új Alkotmány «húsvéti» szövegéhez". In: Az új Alaptörvényröl - elfogadás elött, ed. by Borbély Anett Kubovicsné, András Virányi, 26-31. Budapest: Az Országgyülés Alkotmányügyi és Ügyrendi Bizottsága.

\section{KULTURA CHRZEŚCIJAŃSKA WĘGIER JAKO PRZEDMIOT OCHRONY KONSTYTUCYJNEJ}

Streszczenie

Zgodnie ze znowelizowaną w 2018 r. węgierską Konstytucją, ochrona chrześcijańskiej kultury Węgier stanowi obowiązek wszystkich organów państwa. Konstytucja nie wprowadza ciążącego na państwie zobowiązania odnoszącego się do religii chrześcijańskiej czy do generalnie pojmowanej kultury chrześcijańskiej, lecz odnosi się konkretnie do kulturalnej tradycji kraju. Pomimo uznania kulturowej roli chrześcijaństwa, Konstytucja pozostaje neutralna wobec religii i uznaje wolność religijną. Omawiany w niniejszym artykule przepis konstytucyjny, czyli art. R) ust. 4, wyraźnie wskazuje na chrześcijańskie korzenie kultury węgierskiej. Kultura wyrosła z wiary, lecz wiara nie może się zrodzić z historycznego dziedzictwa, ani tym bardziej z przepisu ustawy zasadniczej. W związku z tym celem ustrojodawcy było niewątpliwie nadanie większego znaczenia tożsamości narodowej.

Słowa kluczowe: tożsamość konstytucyjna; chrześcijaństwo; kultura; Węgry

Ttumaczenie: Daria Bębeniec 